\title{
Tolerance of Sexual Diversity, Gender Equity, and Sexual and Reproductive Rights: Determining Factors of Sexual Education and Awareness in the New Millennium
}

\author{
Miguel Barbosa Fontes', Rodrigo Campos Crivelaro', Alice Margini Scartezini'2, David Duarte Lima3, \\ Alexandre de Araújo Garcia ${ }^{4}$, Rafael Tsuyoshi Fujioka ${ }^{1}$
}

${ }^{1}$ John Snow Brasil Consultancy, Brasilia, Brazil

${ }^{2}$ CaixaSeguradora Institute, Brazil

${ }^{3}$ Department of Public Health, University of Brasilia, Brasilia, Brazil

${ }^{4}$ Opinião Consultancy, Brasilia, Brazil

Email: R.LARO@JOHNSNOW.COM.BR

How to cite this paper: Fontes, M. B., Crivelaro, R. C., Scartezini, A. M., Lima, D. D., de Araújo Garcia, A., \& Fujioka, R. T. (2016). Tolerance of Sexual Diversity, Gender Equity, and Sexual and Reproductive Rights: Determining Factors of Sexual Education and Awareness in the New Millennium. Creative Education, 7, 2035-2046. http://dx.doi.org/10.4236/ce.2016.715204

Received: July 1, 2016

Accepted: September 3, 2016

Published: September 6, 2016

Copyright $\odot 2016$ by authors and Scientific Research Publishing Inc. This work is licensed under the Creative Commons Attribution International License (CC BY 4.0).

http://creativecommons.org/licenses/by/4.0/ (c) (i) Open Access

\begin{abstract}
The objective of the research was to evaluate the level of sexual education and awareness of Brazilian youth regarding sexual diversity, gender equity, and sexual and reproductive rights. The study was approved by the ethics committee of the School of Medicine of University of Brasilia. The Pan American Health Association and the Department of STDs/HIV-AIDS and Viral Hepatitis of the Brazilian Ministry of Health supported this study, and Caixa Seguradora funded the research. Household interviews were conducted with 1208 youth aged 18 to 29 years old, based on a probability sample in 15 states and the Federal District. The research margin of error, standardized regionally and nationally, was $2.8 \%$. A sexual awareness scale was generated, incorporating 15 variables for sexual diversity, gender equity, and sexual and reproductive rights. Adjusted linear regression models were created to identify socio-demographic determinants explaining the variance in the sexual awareness scale. The mean on the scale was 7.8 points. Gender, religious affiliation and education were significantly associated with variation in levels of sexual awareness. As for social determinants, having teachers as the main source of sexuality education, accessing the internet, having an interest in learning, not participating in religious groups, having frequent conversations with parents, frequency of sexual intercourse, and confidence in one's sexual health were all positively associated with higher levels of sexual awareness. Based on socio-demographic determinants positively associated with variations in levels of sexual awareness, interventions should be promoted for reducing
\end{abstract}


stigma and gender inequity, and increasing awareness of sexual and reproductive rights among Brazilian youth.

\section{Keywords}

Evaluation, Sexual Education, Sexual Awareness, Brazilian Youth, KAP Scale

\section{Introduction}

Intolerance of sexual diversity, gender inequity and the question of approaches to sexual and reproductive rights are fundamental dimensions of sexual awareness in the new millennium. The World Association for Sexual Health (WAS) in its Declaration of Sexual Rights of individuals states that one of the main pillars of sexual rights is associated with the "Right to Comprehensive Sexuality Education". That is to say, one should start in the first years of life, but also incorporate interventions that follow the individual through all the cycles of life.

Furthermore, a list of another ten rights associated with gender equity and reproductive health and respect for sexual diversity is outlined. In relation to gender equity and sexual diversity, it states that every individual has the right to free from all forms of discrimination, regardless of sex, gender, sexual orientation, age, race, social class, religion or physical and emotional disability. With regard to reproductive rights, it establishes the principle that people have "the right to decide whether they want to have children, the number and spacing of children, and to have the information and means to do so" (WAS, 1999).

However, it may be seen that the practice of sexuality education, especially for adolescents and young people, is far from having incorporated sexual and reproductive rights in their respective curricula. In a study done in Ottawa, Canada, Martinez \& Phillips (2008) reinforce this argument, showing that research on education in sexual health is lacking in critical analysis through a lens of human rights. The authors point to one of the principal results of the research undertaken, which demonstrated that

"Despite some efforts from the health sector to promote an SRH rights-based approach, our findings show that Ottawa-area teachers and young adults are ill-equipped to articulate SRH rights, and may therefore be unable to prevent gender-stereotypic, racialized or homophobic constructions of adolescent sexuality (Martinez \& Phillips, 2008: p. 141)".

Nevertheless, even taking into account these new dimensions of sexual and reproductive rights, some sexual awareness interventions are still limited to evaluate the knowledge of certain population groups regarding practices of prevention of STDs, unplanned pregnancies, and human sexuality in general. It may be seen that a new approach that is not limited to biological issues, but also provides a socio-cultural treatment, is required, not only in order to stimulate full, healthy sexuality among young people, but also to contribute to reducing gender-related and homophobic violence and 
prejudice, as well as other conflicts based on human sexuality.

Studies have shown the need for comprehensive sexuality education targeted at Brazilian youth and the barriers for its implementation. As Bortolini puts it,

"We have set ourselves a challenge to rethink our own paradigms, in an attempt to construct a practice that not only includes, but also reconsiders and restructures itself, based on the issues before us. This does not mean making additions to the curriculum, but rather constructing a new curriculum and a new practice based on dialog and encounters among different groups and individuals, without failing to take into account the tension implied in conflict, and furthermore perceiving the conflict per se and the differences themselves in their pedagogical potential (Bortolini, 2011: p. 27)".

This being the case, this present study proposes to construct a measure of sexual awareness that contemplates aspects related to tolerance of sexual diversity, gender equity, and sexual and reproductive rights.

\section{Methods}

Following the guidelines for research approved by the Council on Research Ethics of the School of Medicine of the University of Brasilia $(\mathrm{UnB})^{1}$, the questionnaire was pilot tested and data was gathered during the second semester of 2011. The probability sample taken consisted of young people between 18 and 29 years of age, from all regions of Brazil. The questionnaires were applies in randomly selected households, using the census units of the Brazilian Institute of Geography and Statistics (IBGE).

The sample consisted of 1208 young people aged $18-29$, in 15 states and the Federal District as presented in Table 1 . The sampling error was $2.7 \%(p<0.05)$. The table below

Table 1. Sampling process.

\begin{tabular}{|c|c|c|c|}
\hline States & Municipalities & Census Sectors & Households \\
\hline $\begin{array}{l}\text { 1. Amazonas } \\
\text { 2. Bahia } \\
\text { 3. Ceará } \\
\text { 4. Distrito Federal } \\
\text { 5. Goiás } \\
\text { 6. Maranhão } \\
\text { 7. Mato Grosso } \\
\text { 8. Minas Gerais } \\
\text { 9. Pará } \\
\text { 10. Paraná } \\
\text { 11. Pernambuco } \\
\text { 12. Rio de Janeiro } \\
\text { 13. Rio Grande do } \\
\text { Norte } \\
\text { 14. Rio Grande do Sul } \\
\text { 15. Rondônia } \\
\text { 16. São Paulo }\end{array}$ & $\begin{array}{l}\text { - Capitals: } \\
\text { - Stand alone } \\
\text { - Size of municipality in } 3 \\
\text { - } \text { categories: } \\
\text { - Up to } 50,000 \text { inhabitants } \\
\text { - } 50,000-500,000 \text { inhabitants } \\
\text { - }>500,000 \text { inhabitants } \\
\text { - Aged } 18-29\end{array}$ & $\begin{array}{l}\text { - } \quad \text { IBGE } \\
\text { - Simple random selection }\end{array}$ & $\begin{array}{l}\text { - Systematic } \\
\text { selection }\end{array}$ \\
\hline
\end{tabular}

${ }^{1}$ Report CEP-FM no. 026/2011. 
summarizes the sampling process, stratified by size of municipality $(<50,000$ inhabitants, 50,000 - 500,000 inhabitants, and > 500,000 inhabitants).

The pilot test of the questionnaire was done with 30 young people in the Federal District. Factor analysis was performed to verify the validity and consistency of the questions. Based on the factor loadings of the variables and their respective correlations, three domains were established, for sexual awareness knowledge, attitudes and practice.

During the research process, all the questionnaires for which written consent was given in writing were considered. Because the research focused solely on young people legally of age, no authorization of the parents or guardians was required.

After the data had been gathered, a database was generated in Microsoft Excel. After the data input, three members of the research team were designated to check for possible inconsistencies and errors. After the consistency of the database had been confirmed, the spreadsheet was exported to the STATA 9.0 system for statistical data analysis.

Two approaches to statistical analysis were taken: exploratory and explanatory. For exploratory analysis, means, confidence intervals and normality tests were performed for the variables comprising the scale utilized (the dependent variable). In addition, the socio-demographic profile of the sample, along with other independent variables such as the primary source of sexual awareness, personal references, history of alcohol and drug use, and frequency of sexual relations, were analyzed.

For the first explanatory analyses, the normality of the distribution of the main dependent variable (KAP scale) was analyzed (Kaliyaperumal, 2004); with the verification of non-normality, the Generalizing Estimation Equation (GEE) was utilized. For GEE regressions, unadjusted (variable to variable) models and one adjusted model were generated, including the variables of the respondents' socio-demographic profile only. After definition of the adjusted model, the independent variables (source of sexual awareness, level of access to health services, personal references, history of alcohol and drug use and frequency of sexual relations) were tested one by one, for verification of statistical significance.

It should also be pointed out that all the questions in the final questionnaire were approved by representatives of the Pan American Health Organization (PAHO) and by the Department of STD/AIDS and Viral Hepatites of the Ministry of Health.

\section{Results}

In the sample obtained, most of the young people were female (55\%), identified themselves as dark skinned or black (56\%), were high school graduates (43.6\%) and were working $(60 \%)$. However, only $17 \%$ had gone beyond secondary school and $70 \%$ were not studying; the remuneration of most of the young people was equal to or less than twice the minimum wage.

In relation to aspects of sexuality, $93 \%$ reported that they had had sex in the previous 12 months, and $21.9 \%$ singled out friends and colleagues as their main source of sexual awareness. Parents or guardians played that role in $20.1 \%$ of the cases. For $34.7 \%$, the mother is the main source of support when they need to discuss personal problems. 
The father is in sixth place, with $6.5 \%$, behind friends, partners and siblings. Furthermore, although $54.3 \%$ say they always or sometimes talk with their parents or guardians, the least discussed topics are violence, drugs and sexuality.

For the explanatory research model, a scale of 15 key questions was drawn up, reflecting aspects related to tolerance of sexual diversity, gender equity and sexual and reproductive rights. The affirmations for each domain are to be found below.

- Sexual and Reproductive Rights

1) The school must provide information on sexual and reproductive health to students of both sexes.

2) Sexual awareness stimulates the onset of sexual activity.

3) Sexuality education should be provided only at home.

4) Adolescents and young people have the right to decide when to have sex for the first time.

5) Adolescents and young people have the right to decide who to have sexual relations with.

- Gender Equity

1) Women who dress in a provocative manner can't complain if they suffer sexual violence.

2) The man needs sex more than the woman.

3) If a man betrays a woman, she may hit him.

4) A man may strike a woman if she doesn't want to have sex with him.

5) If a woman betrays a man, he may hit her.

6) A woman may humiliate a man if he doesn't want to have sex with her.

\section{- Tolerance of Sexual Diversity}

1) I would never have a lesbian or gay friend.

2) It would never bother me to have a gay or lesbian teacher.

3) It wouldn't bother me to discover that my brother is gay or my sister is lesbian.

4) Homosexual couples may adopt children.

For each question, one point was given to the respondent, on a scale ranging from -15 , for a deficient sexual awareness and less notion of gender equality, to 15 points when the young person has more knowledge and is more tolerant in relation to other people's sexuality (see Table 2 and Table 3). On this scale, Brazilian young people scored an average of 7.81 points.

The score on each variable ranged from 1 to -1 , depending on the response to each variable. For example, for the attitudinal affirmation, "Women who dress in a provocative manner can't complain if they suffer sexual violence", the responses had the following scores on the Likert scale:

- Totally agree $=-1$ point.

- Agree in part $=-0.5$ point .

- Neither agree nor disagree $=0.0$ point

- Disagree in part $=0.5$ point.

- Totally disagree $=1.0$ point. 
Table 2. KAP scale (dimensions).

\begin{tabular}{ccc}
\hline KAP & Full Value & Minimum Value \\
\hline 05 Attitudes toward Sexual Awareness & 5 & -5 \\
06 Attitudes of Equity toward Gender & 6 & -6 \\
04 Attitudes of Equity toward Sexual Orientation & 4 & -4 \\
Total & 15 & -15 \\
\hline
\end{tabular}

Table 3. KAP scale (mean value for each variable).

\begin{tabular}{|c|c|c|c|c|c|}
\hline Item & $\begin{array}{l}\text { Totally } \\
\text { Agree }\end{array}$ & $\begin{array}{l}\text { Agree in } \\
\text { Part }\end{array}$ & $\begin{array}{c}\text { Neither Agree } \\
\text { nor Disagree }\end{array}$ & $\begin{array}{l}\text { Disagree in } \\
\quad \text { Part }\end{array}$ & $\begin{array}{c}\text { Totally } \\
\text { Disagree }\end{array}$ \\
\hline $\begin{array}{l}\text { 1) The school should provide information on } \\
\text { sexual and reproductive health for students of } \\
\text { both sexes. }\end{array}$ & $75.75 \%$ & $11.84 \%$ & $4.80 \%$ & $1.99 \%$ & $2.15 \%$ \\
\hline $\begin{array}{l}\text { 2) The man needs sex more than the woman } \\
\text { does. }\end{array}$ & $24.83 \%$ & $13.33 \%$ & $19.95 \%$ & $12.50 \%$ & $23.33 \%$ \\
\hline $\begin{array}{l}\text { 3) A man may strike a woman if she doesn't } \\
\text { want to have sex with him. }\end{array}$ & $5.96 \%$ & $0.99 \%$ & $2.24 \%$ & $7.70 \%$ & $80.22 \%$ \\
\hline 4) If a woman betrays a man, he may hit her. & $3.81 \%$ & $2.73 \%$ & $4.88 \%$ & $8.11 \%$ & $77.73 \%$ \\
\hline $\begin{array}{l}\text { 5) Women who dress in a provocative manner } \\
\text { can't complain if they suffer sexual violence. }\end{array}$ & $14.16 \%$ & $12.33 \%$ & $11.34 \%$ & $11.92 \%$ & $47.35 \%$ \\
\hline $\begin{array}{l}\text { 6) A woman may humiliate a man if she } \\
\text { doesn't want to have sex with him. }\end{array}$ & $3.31 \%$ & $2.07 \%$ & $5.03 \%$ & $8.61 \%$ & $78.64 \%$ \\
\hline 7) If a man betrays a woman, she may hit him. & $12.50 \%$ & $4.80 \%$ & $7.20 \%$ & $7.95 \%$ & $65.48 \%$ \\
\hline $\begin{array}{l}\text { 8) Adolescents and young people have the right } \\
\text { to decide when to have sex for the first time. }\end{array}$ & $57.53 \%$ & $15.89 \%$ & $9.27 \%$ & $5.71 \%$ & $8.61 \%$ \\
\hline $\begin{array}{l}\text { 9) Adolescents and young people have the right } \\
\text { to decide who to have sexual relations with. }\end{array}$ & $68.54 \%$ & $14.49 \%$ & $6.04 \%$ & $3.15 \%$ & $5.38 \%$ \\
\hline 10) I would never have a lesbian or gay friend. & $7.53 \%$ & $3.97 \%$ & $9.77 \%$ & $8.86 \%$ & $67.72 \%$ \\
\hline $\begin{array}{l}\text { 11) It bothers me to have a gay or lesbian } \\
\text { teacher. }\end{array}$ & $6.54 \%$ & $2.73 \%$ & $9.19 \%$ & $10.02 \%$ & $69.70 \%$ \\
\hline $\begin{array}{l}\text { 12) It would bother me if I discovered by } \\
\text { brother is gay or my sister is lesbian. }\end{array}$ & $14.74 \%$ & $7.45 \%$ & $12.67 \%$ & $10.10 \%$ & $50.33 \%$ \\
\hline 13) Homosexual couples may adopt children. & $38.16 \%$ & $12.83 \%$ & $13.00 \%$ & $7.37 \%$ & $21.36 \%$ \\
\hline $\begin{array}{l}\text { 14) Sexual awareness stimulates the onset of } \\
\text { sexual activity. }\end{array}$ & $28.81 \%$ & $17.55 \%$ & $11.92 \%$ & $10.93 \%$ & $28.23 \%$ \\
\hline $\begin{array}{l}\text { 15) Sexual awareness should only be taught at } \\
\text { home. }\end{array}$ & $9.77 \%$ & $5.13 \%$ & $7.20 \%$ & $13.74 \%$ & $61.42 \%$ \\
\hline $\begin{array}{l}\text { 16) Sexual awareness should only be taught at } \\
\text { home. }\end{array}$ & $9.77 \%$ & $5.13 \%$ & $7.20 \%$ & $13.74 \%$ & $61.42 \%$ \\
\hline
\end{tabular}

Cronbach's alpha, a test of consistency, was 0.7. That is to say, it showed a significant level of consistency in measurement of level of sexual awareness, based on the variables tolerance of diversity, gender equity, and sexual and reproductive rights. The Shapiro-Wilk test of normality (Vasicek, 1976) was also utilized. Non-normality of the dis- 
tribution of scores on the young people's scale of sexual awareness was found. Based on that finding, Generalizing Estimation Equation (GEE) linear regression models were employed.

As may be seen in the above Table 4, the profile variables that are directly associated with an explanation of variation on the sexual awareness scale are related to gender, schooling and religious belief. In relation to gender, it was found that in general, young women have a higher level of sexual awareness than young men. Their mean score on the scale was 8.36 , while that of the men was 7.15 .

With regard to schooling, the longer the young person studied, the higher the level of sexual awareness. Those who have only finished elementary school reached 6.89 points. College graduates had a 9.36 point average. Another aspect influencing the level of sexual awareness is having failed to pass a year of school at least once: there was a 0.72 point decline for those who had failed.

Figure 1 below also presents the distribution of the scale, by level of schooling.

Young people who identify themselves as Evangelical or Protestant also have a lower average level of KAP regarding reproductive health. Their mean is 7.31 points, 1.43 points below the non-Evangelicals.

Table 4. Findings for the linear regression, utilizing the adjusted and non-adjusted variables of young people's socio-demographic profile.

\begin{tabular}{|c|c|c|c|c|c|c|}
\hline Number of Observations & 1208 & & & & & \\
\hline$P>\mathrm{F}$ & 0.00 & & & & & \\
\hline $\mathrm{R}^{2}$ & 0.12 & & & & & \\
\hline Linear Regression & Coefficient & $\begin{array}{c}\text { Robust } \\
\text { Standard Error }\end{array}$ & $\mathrm{t}$ & $P>\mathrm{I} \mathrm{t} \mathrm{I}$ & \multicolumn{2}{|c|}{$\begin{array}{c}\text { 95\% Confidence } \\
\text { Interval }\end{array}$} \\
\hline \multicolumn{7}{|l|}{ Scale } \\
\hline Age & 0.36 & 0.03 & 1.12 & 0.26 & -0.03 & 0.10 \\
\hline Male Gender & -1.06 & 0.23 & -4.65 & 0.00 & -1.50 & -0.61 \\
\hline White & 0.31 & 0.24 & 1.31 & 0.19 & -0.16 & 0.77 \\
\hline Family Income & 0.00 & 0.00 & -1.59 & 0.11 & 0.00 & 0.00 \\
\hline Religion Evangelical & -1.43 & 0.25 & -5.75 & 0.00 & -1.92 & -0.94 \\
\hline \multicolumn{7}{|l|}{ Elementary } \\
\hline Education & -1.85 & 0.32 & -5.83 & 0.00 & -2.47 & -1.23 \\
\hline High school incomplete & -0.33 & 0.32 & -1.03 & 0.31 & -0.97 & 0.30 \\
\hline Higher Education & 0.62 & 0.30 & 2.06 & 0.04 & 0.03 & 1.21 \\
\hline Has Failed to Pass & -0.72 & 0.23 & -3.08 & 0.00 & -1.17 & -0.26 \\
\hline Not Heterosexual & -0.89 & 0.61 & -1.47 & 0.14 & -2.08 & 0.30 \\
\hline \multicolumn{7}{|l|}{ Independent Variable } \\
\hline Constant & 8.74 & 0.80 & 10.89 & 0.00 & 7.17 & 10.32 \\
\hline
\end{tabular}

Reference group female, non-white, non-evangelical, high school graduate, has not failed, heterosexual. 
Using these main variables of the socio-demographic profile, GEE-adjusted linear regression models were tested for each of the five social determinants utilized in the research (source of sexual awareness, sexual confidence, participation in social-religious groups, personal references, history of alcohol use and frequency of sexual relations).

Of the different sources of sexual awareness listed in the questionnaire, only having the church as the main source of sexuality education is associated with a negative variation in level of sexual awareness. This occurs regardless of race, gender, schooling, income or sexual orientation, as shown in the adjusted regression models below (Table 5).

On the average, having the church as the principal source of sexual awareness reduces the score on the scale of tolerance of sexual diversity, gender equity and sexual and reproductive rights by 1.64 points. Furthermore, a history of participation in a religious group is also associated with a reduction in the level of sexual awareness. On the average, participation in religious groups reduces the score on the scale of sexual awareness by 0.81 points.

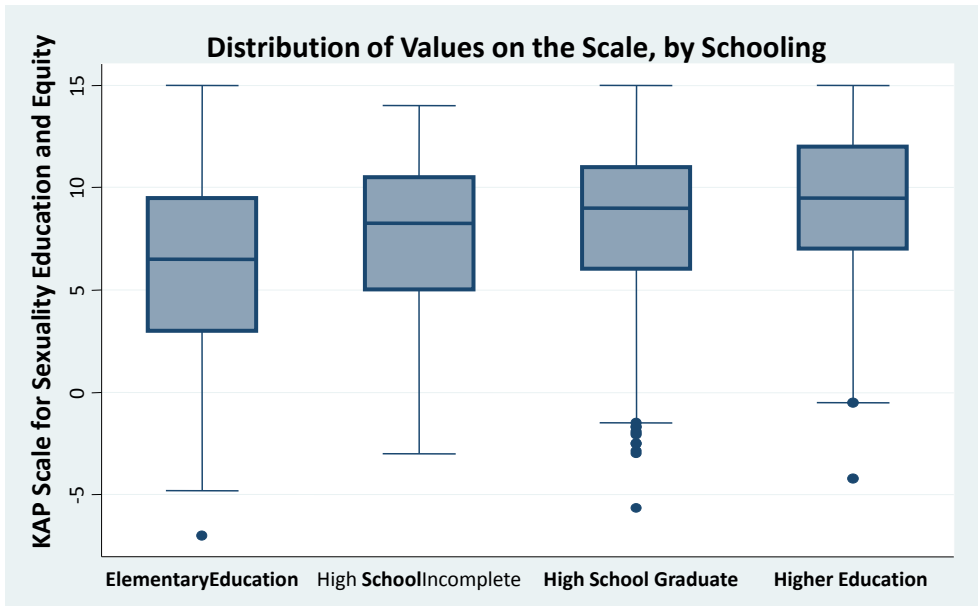

Figure 1. Distribution of values on the scale by schooling.

Table 5. Regression results for independent variables adjusted for Age, gender, race, family income, religion, education, sexual orientation, and school failure.

\begin{tabular}{|c|c|c|c|c|c|c|c|}
\hline Number of Observations & 1208 & & & & & & \\
\hline Linear Regression & Coefficient & $\begin{array}{l}\text { Robust } \\
\text { Standard Error }\end{array}$ & $\mathrm{t}$ & $P>\mathrm{It} \mathrm{I}$ & \multicolumn{2}{|c|}{$\begin{array}{l}95 \% \text { Confidence } \\
\text { Interval }\end{array}$} & \multirow[t]{2}{*}{$\begin{array}{l}\text { e Model's } \\
\text { Constant }\end{array}$} \\
\hline \multicolumn{7}{|l|}{ Scale } & \\
\hline 1st Source of Sexual Education-Church & -1.64 & 0.59 & -2.76 & 0.01 & -2.80 & -0.48 & 8.79 \\
\hline Main Reference Person-Parents & 1.44 & 0.46 & 3.12 & 0.00 & 0.53 & 2.34 & 8.57 \\
\hline Main Reference Person-Teacher & 1.84 & 0.91 & 2.02 & 0.04 & 0.05 & 3.64 & 8.70 \\
\hline $\begin{array}{c}\text { Knowing where to Find or Look for } \\
\text { Information and Treatment on Sexual } \\
\text { Health }\end{array}$ & 1.24 & 0.31 & 4.00 & 0.00 & 0.63 & 1.85 & 7.76 \\
\hline $\begin{array}{l}\text { Confidence about How to Have a Full } \\
\text { Sexual Life }\end{array}$ & 1.05 & 0.22 & 4.78 & 0.00 & 0.62 & 1.49 & 8.34 \\
\hline
\end{tabular}


On the other hand, discussing sexuality with one's parents, having teachers as reference persons, and internet access show a significant association with increase in level of sexual awareness. In relation to conversation with one's parents, the adjusted regression below shows that giving priority to matters related to sexuality increases the score on the sexual awareness scale by 1.43 points on the average. As for the main reference person being the teacher, this contributes to a mean increase of 1.84 points on the scale of sexual awareness. The internet also plays an important role in learning, with a contribution coefficient of 1.09 on the scale of sexual awareness.

Young people's level of confidence regarding how to access information on sexual health, avoid STD/AIDS and know how to avoid undesired pregnancy are also important social determinants for explaining positive variation on the sexual awareness scale. As shown by the results of the adjusted regression model below, this yields a coefficient of 1.24 on the scale of sexual awareness. With regard to confidence about how to avoid STD/AIDS, the coefficient is 0.86 . As for confidence regarding how to prevent undesired pregnancy, the coefficient hit 1.25 points.

Finally, young people's level of confidence about how to have a full sex life is associated with a significant positive variation on the scale of sexual awareness. As shown in the adjusted model below, regardless of age, race, income, schooling or sexual orientation, young people who feel confident about their sex life have a mean level of sexual awareness 1.05 points above those who do not agree with this affirmation.

\section{Discussion and Conclusion}

It was verified that the findings of this study were consistent with our review of Brazilian and international literature. Comprehension of the implications and importance of acceptance of gender equity, sexual diversity, and sexual and reproductive rights becomes an essential parameter for sexual awareness in the new millennium and a full and satisfactory sex life.

It is of fundamental importance to create channels of dialog between parents and their children, giving priority to topics related to sexuality. The research reaches this conclusion after confirming that frequent conversations with parents, especially when the main topic is sex, significantly broaden positive attitudes in relation to sexual diversity, gender equity, and sexual and reproductive rights.

This finding reinforces several studies already conducted on the importance of parents in the sexual awareness of their offspring. Although friends are cited as the main source of sexual awareness and parents are often in the second place, the importance of dialog with parents cannot be overemphasized. Quite the contrary, the study shows that the association between higher levels of sexual awareness and parental engagement is significant. In studies conducted in Brazil, Pereira et al. (2011) state that "certain characteristics of adolescents living in needier environments have been identified. The existence of less information, less communication with parents and a greater tendency toward risky behaviors stand out" (Pereira et al., 2011: p. 77).

That is to say, adult reference persons are fundamental, and sexual awareness re- 
quires frank and open discussion between adults and youth. This study also showed that having the teacher as a reference person, accessing the internet, being interested in new knowledge and experiences, and knowing when to find information on sexual health provided a higher level of social education focusing on rights. These social determinants have also been widely confirmed in other studies of adolescents, such as Pereira et al. (2011), Gonçalves et al. (2013), Santos (2013), and Sampaio et al. (2010).

Therefore, the schools should more frequently discuss topics of sexual awareness. For that to happen, it is necessary to train all the teachers to be reference persons in that area for their students. Just as the question of environmental sustainability has become an interdisciplinary topic in the schools, sexual and reproductive rights can and should be discussed and utilized as examples in all subjects. Logically, today's deficient sexual awareness in the schools is not just a Brazilian problem. Studies by Foster et al. (2011), Klinkert (2010), and Mlyakado (2013) are unambiguous in that regard. In Portugal, Macário (2010) also demonstrates that although the legislation already does provide for cross disciplinary sexual awareness,

"The strategies utilized should be more participatory, attempting to employ a project-based methodology. Teachers must not make an a priori judgment that their students are 'too young', because more important than age is the degree of maturation and the experiences” Macário (2010).

Religious beliefs may limit comprehensive sexual awareness for the new millennium. As has been shown, participation in religious groups and having the church as the main source of sexual awareness do not contribute to an increased level of sexual awareness, including questions of tolerance for sexual diversity, gender equity, and sexual and reproductive rights. Quite the contrary, the association is negative and significant.

Even considering that religious practice and belief are variables that are hard to define, certain studies, such as those by Melo et al. (2010) and Marinho et al. (2011), have demonstrated the more "conservative" character of young Protestants in relation to human sexuality. Silva et al., IN Coutinho \& Miranda-Ribeiro (2014), show that young Protestants and Pentacostals were those who least agreed with affirmations that sex was a source of pleasure and satisfaction, and a physical need like hunger and thirst (Silva et al., in Coutinho \& Miranda-Ribeiro, 2014).

Furthermore, the preeminent need is to strengthen young people's confidence with regard to having a full sex life, knowledge of ways to prevent pregnancy, knowing where to find treatment and information on questions of sexual health, and the confidence to protect themselves against the STDs. The findings of this study reveal that these are determining factors for a significant increase in sexual awareness based on sexual and reproductive rights. This conclusion is also consistent with the results of other Brazilian and international studies of the topic, such as those by Martinez \& Phillips (2008), Barbosa et al. (2015), and Miyakado (2013).

Despite the robustness of the findings of this study, certain limitations that may compromise the validity and consistency of the findings should be highlighted. In relation to validity, even with pilot testing, some questions may not have been adequately 
understood by young people from certain regions of the country. This is because the meaning of some expressions may vary among the regions of Brazil.

Furthermore, although the scale of sexual awareness may be utilized as a good parameter, it does not cover all the issues related to tolerance for sexual diversity, gender equity, and sexual and reproductive rights. That is to say, the scale does not include all the defining elements of sexual awareness. More specific questions regarding procedures for prevention, treatment, and education for reproductive health might increase the consistency of the scale. Nevertheless, it should be stressed that even with this limitation, the parameters utilized are applied in a homogeneous manner to all the interviewees.

Sexual awareness is, first and foremost, a human and individual right. Everyone, regardless of race, schooling, gender, age and sexual orientation, etc., should receive explanations regarding their sexual and reproductive rights. This study shows that among Brazilian young people, that is not yet the case. Certain segments of the population, such as Brazilian young people, are still more vulnerable; and public and private intervention is of fundamental importance for significant expansion and ownership of sexual and reproductive rights.

\section{References}

Barbosa, S. M., Dias, F. L. A., Pinheiro, A. K. B., Pinheiro, P. N. C., \& Vieira, N. F. C. (2015). Educational Games as an Educational Strategy for the Health of the Youth and STD/AIDS Prevention. Revista eletrônica de Enfermagem [Internet Journal], 12, 337-341.

Bortolini, A. (2011). Sexual Diversity and Gender in Schools. Revista Espaço Acadêmico, 11, 27-37.

Coutinho, R. Z., \& Machado-Ribeiro, P. (2014). Religion, Religiosity, and Sexual Initiation among Youth: Half Century of Research. Revista Brasileira de Estudos de População, 31, 333-365.

Foster, L. R., Byers, E. S., \& Sears, H. A. (2011). Middle School Students' Perceptions of the Quality of the Sexual Health Education Received from Their Parents. The Canadian Journal Human Sexuality, 20, 55-65.

Gonçalves, F. C., Faleiro, J. H., \& Malafaia, G. (2013). Sexual Education in Family and School context: Impasses and Challenges. Holos, 5, 251-263.

http://dx.doi.org/10.15628/holos.2013.784

Kaliyaperumal, K. (2004). IEC; Expert, Diabetic Retinopathy Project. Guideline for Conducting a Knowledge, Attitude, and Practice (KAP) Study. Community Ophthalmology, 4, 7-9.

Klinkert, M. P. P. (2010). Why Youth in Medellín Don't Follow-Up on the Sexual Education They Recieve-Youth, Parents, and Teachers Discussions. Cuestiones Teológicas, 37, 369-397.

Macário, R. M. B. (2010). Sexual Education in a School Environment: Another Year Zero? Thesis, Montenegro: Algarve University.

Marinho, S., Anastácio, Z., \& Carvalho, G. S. (2011). Development and Implementation of Sexual Education Projects: Analysis of Biological, Psychological, and Social Dimensions of Sexuality. Repositórium [Institutional Repository of the University of Minho].

Martinez, A., \& Phillips, K. P. (2008) Challenging Ethno-Cultural and Sexual Inequities: An Intersectional Feminist Analysis of Ottawa Teachers, Health Partners and University Students' Views on Adolescent Sexual and Reproductive Rights. The Canadian Jornal Human Sexuality, 
17, 141-159.

Melo, E. M. O., Arruda, D. P., \& Alencar, H. F. (2010). What's Said and Unsaid about Sexual Education: A Discursive Production. Psicologia Ciência e Profissão, 30, 346-361.

Mlyakado, B. P. (2013). Schoolgirls' Knowledge of, and Efforts against, Risky Sexual Activity: The Needs for sexuality education in Schools. International Journal of Education, 5, 69-80.

http://dx.doi.org/10.5296/ije.v5i1.2825

Pereira, S., Matos, M. G., \& Leal, I. (2011). Inequity, Ethnicity, and Sexual Education.Psicologia, Saúde \&Doenças, 12, 77-90.

Sampaio, J., Santos, R. C., Paixão, L. A., \& Torres, T. S. (2010). Sexual Health Promotion: Challenges of the São Francisco valley. Psicologia \& Sociedade, 22, 499-506. http://dx.doi.org/10.1590/S0102-71822010000300010

Santos, M. W. B (2013). Educational Media and Classes on Sexual Orientation-A Viable Proposal to Connect School and Real Life Knowledge? Revista de Ciências da Educação, Americana, 2, 80-99.

Vasicek, O. A. (1976). Rest for Normality Based on Sample Entropy. Journal of the Royal Statistical Society, Series B (Methodological)

World Association for Sexual Health (WAS) (1999). Declaration of Sexual Rights. Hong Kong: WAS.

Submit or recommend next manuscript to SCIRP and we will provide best service for you:

Accepting pre-submission inquiries through Email, Facebook, LinkedIn, Twitter, etc.

A wide selection of journals (inclusive of 9 subjects, more than 200 journals)

Providing 24-hour high-quality service

User-friendly online submission system

Fair and swift peer-review system

Efficient typesetting and proofreading procedure

Display of the result of downloads and visits, as well as the number of cited articles

Maximum dissemination of your research work

Submit your manuscript at: http://papersubmission.scirp.org/ 